\title{
Impact of earthquakes on sex ratio at birth: Eastern Marmara earthquakes
}

\section{Depremlerin doğumda cinsiyet oranına etkisi: Doğu Marmara depremleri}

\author{
Emek Doğer, Yiğit Çakıroğlu, Şule Yıldırım Köpük, Yasin Ceylan, Hayal Uzelli Şimşek, Eray Çalışkan \\ Department of Gynecology and Obstetrics, Kocaeli University Faculty of Medicine, Kocaeli, Turkey
}

\section{Abstract}

Objective: Previous reports suggest that maternal exposure to acute stress related to earthquakes affects the sex ratio at birth. Our aim was to examine the change in sex ratio at birth after Eastern Marmara earthquake disasters.

Material and Methods: This study was performed using the official birth statistics from January 1997 to December 2002 - before and after 17 August 1999, the date of the Golcuk Earthquake - supplied from the Turkey Statistics Institute. The secondary sex ratio was expressed as the male proportion at birth, and the ratio of both affected and unaffected areas were calculated and compared on a monthly basis using data from gender with using the Chi-square test.

Results: We observed significant decreases in the secondary sex ratio in the 4th and 8th months following an earthquake in the affected region compared to the unaffected region $(p=0.001$ and $p=0.024)$. In the earthquake region, the decrease observed in the secondary sex ratio during the 8 th month after an earthquake was specific to the period after the earthquake.

Conclusion: Our study indicated a significant reduction in the secondary sex ratio after an earthquake. With these findings, events that cause sudden intense stress such as earthquakes can have an effect on the sex ratio at birth.

(J Turkish-German Gynecol Assoc 2013; 14: 92-7)

Key words: Earthquakes, sex ratio at birth

Received: 18 April, 2013

Accepted: 09 May, 2013
Özet

Amaç: Önceki çalışmalarda, depremler ile ilişkili maternal akut stres maruziyetinin doğumda cinsiyet oranına etkisi bildirilmişti. Bu çalışmada amacımız Doğu Marmara deprem felaketlerinden sonra doğumda cinsiyet oranındaki değişimi incelemekti.

Gereç ve Yöntemler: Bu çalışma Türkiye İstatistik Kurumu'ndan (TUiK) sağlanan Ocak 1997 ve Aralık 2002 yılları arasında, -17 Ağustos 1999 Gölcük depreminden önce ve sonra- resmi doğum istatistikleri kullanılarak gerçekleştirildi. Sekonder cinsiyet oranı, doğumda erkek oranı olarak ifade edildi ve sekonder cinsiyet oranı, etkilenmiş ile etkilenmemiş bölgelerin ikisinde de cinsiyet verileri ve ki-kare testi kullanılarak aylık bazda hesaplandı ve karşılaştırıldı.

Bulgular: Biz Gölcük depreminden sonraki 4. ve 8. aylarda etkilenmiş bölgede, etkilenmemiş bölge ile karşılaştırıldığında, sekonder cinsiyet oranında anlamlı azalma olduğunu gözledik (sırası ile $p=0.001$ ve $p=$ 0.024). Deprem bölgesinde, depremden sonraki 8 . ayda sekonder cinsiyet oranında gözlenen azalma deprem sonrasına özgü idi.

Sonuç: Çalışmamız deprem sonrası sekonder cinsiyet oranında anlamlı azalma olduğunu gösterdi. Bu bulgular ile deprem gibi ani yoğun strese neden olan olayların doğumda cinsiyet oranı üzerine etkili olduğu göz önünde bulundurulmalıdır.

(J Turkish-German Gynecol Assoc 2013; 14: 92-7)

Anahtar kelimeler: Depremler, doğumda cinsiyet oranı

Geliş Tarihi: 18 Nisan $2013 \quad$ Kabul Tarihi: 09 Mayıs 2013

\section{Introduction}

The sex ratio of females to males at birth is called the secondary sex ratio; the incidence in humans is known to be approximately 1:02 to 1:06 (1). The secondary sex ratio (SSR) is associated with many factors that vary between communities and over the years. In the literature, there have been studies indicating an interaction between the ratios of race, geographical region, the environmental temperature, seasonal changes, and social and country-specific factors such as socio-economic development (2-6). In addition, earthquakes, floods, famine periods, environmental disasters, wars, natural or man-made disasters, such as intense psychological and physical stress caused by the individual, and the society's general health status of pregnant women and pregnancy outcomes can influence the sex ratio at birth, which are likely to change (7-10). Fukuda et al. (7), Saadat et al. (11), Torch et al. (12), and Tourikis et al. (13) investigated the Kobe (Japan) earthquake, the Ban (Southern Iran) earthquake, the Tarapaca (Chile) earthquake, and the Zakynthos (Greece) earthquake, respectively, and reported a decrease in male births compared to female births in the period after the earthquake; in other words there was a decrease in the female secondary sex ratio. These findings suggest a better adaptation process in humans, as well as the size of the damage caused by an earthquake on society. The effects of both natural and man-made disasters can occur many years later, and babies born during stressful periods may encounter increased health problems and increased mortality rates in the future (14). The first sign of deterioration in public health at birth after natural disasters over the years may be a change in sex ratios. 
Movement in the North Anatolian Fault Zone caused two devastating earthquakes in the Eastern Marmara Region. The first earthquake epicentered on Gölcük-Izmit city (17 August, 1999) and was classified as one of the world's six deadliest earthquakes in the 20th century; 87 days later, a second earthquake hit Düzce city (12 November, 1999). According to official records, 18,287 people died and 46,857 were injured. A total of 108,861 buildings, schools and workplaces were destroyed by earthquakes, 1.1 million people became homeless and, especially due to inadequate rescue and support services, communication and shelter systems, the whole nation was shaken and more than 16 million people were impacted (15).

In this study, we evaluated the sex ratio at birth before and after the Eastern Marmara earthquakes compared to the control region.

\section{Material and Methods}

This study was performed using the official birth statistics in January 1997 and a total of 72 months up to December 2002, which were supplied from Turkey Statistics Institute (Turkstat). The secondary sex ratio was expressed as the male proportion at birth, i.e. males/females.

The movements of the North Anatolian Fault Zone caused the Gölcük-Izmit earthquake (17 August, 1999, magnitude on Richter scale 7.8, on Mercalli scale category X: disastrous) and the Düzce earthquake (12 November, 1999, magnitude on Richter scale 7.5, on Mercalli scale category IX: ruinous) (16). Comparisons before and after the earthquake due to the size of the impact of Gölcük earthquake were considered as a reference point. The secondary sex ratio at birth in the affected area (study group) in the eastern Marmara region earthquakes was calculated on a monthly basis using gender data. The unaffected area (control group), was accepted as a location approximately 400-450 km from the shock during the earthquake, in the Mediterranean region, without any destruction or death, and ratios were calculated on a monthly basis using data. In order to demonstrate factors such as changes in season and agricultural work that may affect the results of our study, we identified the region on the same meridian that was unaffected by the earthquake. The Western Anatolia, the Black Sea Region, and the Mediterranean Region were deemed appropriate as unaffected regions since all of the Western Anatolia was affected by the earthquake, the Black Sea region was on the same earthquake fault line, and the Mediterranean region had a cosmopolitan structure, but the eastern Marmara region has heavy industrialisation and the revenue of the Mediterranean region was derived from tourism and agriculture. The effects of out-migration after the earthquake in the eastern Marmara region and the summer seasonal movements causing an increase in population in the Mediterranean region according to statistics could not be assessed in the study. All data were analysed using SPSS version 12.0 (SPSS Inc., Chicago, IL, USA) and Statistica Program 5.0 (StatSoft Inc., Tulsa, OK, USA). Statistical analysis of the sex ratio was performed using the Chi-square test. The significant differences were defined as a $\mathrm{p}$ value less than 0.05 .

\section{Results}

During the five-year period examined in this study, 800,742 male and 762,356 female babies formed a total cohort of $1,563,098$; the overall SSR was 51.22. Of the deliveries, 627,743 took place in the Eastern Marmara region and 935,355 took place in the Mediterranean region; the SSR in eastern Marmara and the Mediterranean regions were 50.74 and 51.55 respectively $(\mathrm{p}=0.959)$. Compared to the previous 12 months and the 12 months immediately after the earthquake, while the birth rate decreased $(2.66 \%)$ in the earthquake area, the rate increased $(4.42 \%)$ in the unaffected region.

Sex changes in rates between regions were evaluated monthly and revealed a significant decrease in the secondary sex ratio in the 4th month (December, 1999) and 8th month (April, 2000) following the Gölcük earthquake in the eastern Marmara region compared to the Mediterranean region $(p=0.001$ and $p=0.024)$. The statistically significant change observed between the two regions in December was also observed in December 1998, December 2000 and December 2001. In fact, in both regions, there was a significant difference between December and January births. This result seems to be related to changes in seasonal population registers. The reasons for the difference observed in the Eastern Marmara region in December might be the legal 30 day notice period in Turkey for registration and the common tradition of birth registration of babies born in December to make their ages one year younger according to records. A significant increase was observed 3 months prior to the earthquake (May 1999) in the SSR only specific to that month $(p=0.046)$. The statistically significant reduction in the secondary sex ratio observed in April 2000 was not observed in any other month during the study period. A pregnancy occurring after ovulation in August 1999 would be expected to be born in May 2000; in our study, we did not detect any significant changes in SSR in May $2000(\mathrm{p}=0.595)$. Also, no significant change has been observed in SSR since then (Figure 1). The decrease observed in male infants in the affected area in April 2000 when compared to male infants in April 2001 and April 2002 was significant $(p=0.032$ and $p=0.049$, respectively).

\section{Discussion}

Hansen et al. (17) have examined the effects of individual intense stress on SSR and revealed a decrease in SSR after such

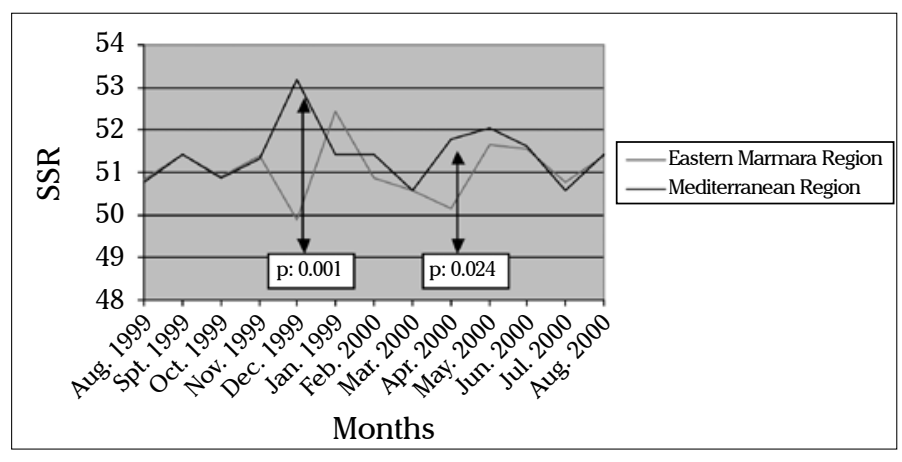

Figure 1. Sex ratio changes after earthquakes in regions on monthly basis 
events leading to severe stress, such as a spouse's serious illness or loss of a child or a husband starting 12 months before conception onwards, including the periconceptional period in the first trimester. However, Khashan et al. (18) expanded their research by adding all births in the next 10 years in the cohort, and revealed a slight decrease that was not statistically significant in the birth sex ratio; Obel et al. (19) and Subbaraman et al. (20) in African-American patient groups have supported the evidence provided by Hansen et al. (17). Hansen et al. (17) and Obel et al. (19) calculated OR in patients with stress and identified ORs as 0.65 and 0.85 , respectively. In these studies, the SSR of the control groups were 1 and 1.07, respectively.

Large earthquakes that may impair the mental health of an individual are a common cause of stress. After the Golcuk and Duzce earthquakes, post-traumatic stress disorder, major depression, panic disorder, obsessive-compulsive disorders, generalised anxiety disorder, phobias, and suicidal tendency were found to be increased and remain high for years (21). This can have a disastrous impact on mental health in pregnant women, and, after a large earthquake, minor psychiatric problems are seen in 1/3 of pregnant women (22). The possibility of shortening the duration of the pregnancy, abortion rate, preterm birth rate and twin pregnancy, the foetus brain development retardation, ear malformations, facial cleft abnormalities and changes in sex ratios at birth have been reported as a cause of severe psychological stress just before pregnancy or during pregnancy $(17,19,20,23-26)$.

Studies investigating the Kobe earthquake, the Ban earthquake, the Tarapaca earthquake, and the Zakynthos earthquake revealed a decrease in the secondary sex ratio in the period after the earthquake (7, 11-13). The ways in which psychological stress of the earthquake reduces the sex ratio at birth are controversial. The reason for the reduction of SSR might be a reduction of male fertilisation (reduction in the reflection of the primary sex ratio), or a higher loss of males than females after fertilisation (direct reduction in SSR). Support for the hypothesis of reduced male fertilisation can be found in the study by Fukuda et al. of the Kobe earthquake $(7,27)$. In these studies, it has been shown that the stress, especially in people who have lost relatives and whose houses were destroyed in the earthquake, reduces coitus frequency, sperm motility for 2-9 months, and also a reduction in SSR nine months after the earthquake. Although unproven, Y-bearing sperm with loads that are lower than $\mathrm{X}$ oocyte achieve an advantage (28). While a decrease in coitus frequency results in the possibility of fertilisation coincident with late menstruation, due to thickening of cervical mucus associated with low sperm motility, the advantage resulting from the loss of Y-bearing sperm, and consequently the rate of progression is likely to decrease in the primary sex ratio. In this situation, because of the reduced male fertilisation, the SSR will change against males, and the male and female birth rates will be found to be closer to each other. High coitus frequency in Micronesia and low SSR related with thickened cervical mucus in clomiphene citrate cycles favour this hypothesis, while publications with no relation of SSR to the timing of intercourse, insemination time, and follicular phase length provide evidence against (29-32).
Trivers-Willard hypothesis suggests a favour of female reproduction in women with poor health status and male reproduction in women with good health status (33). At a time of scarce resources, because a boy has a high probability of growing faster and being more resource-consuming, as well as a high probability of loss before reaching reproductive age, instead of giving birth to a boy, a girl summarises the efficiency of this hypothesis. Despite strong evidence confirming this hypothesis in animals, it is not easy to achieve similar results in humans (34). In groups of patients with anorexia and bulimia, studies have indicated a decrease of male live births, sex ratios decreased secondary to diabetes in women, and the poor health status of mothers giving birth to female babies; this supports the idea $(35,36)$. In the study investigating the shortage of grain in China in 1959-1961 it was reported that adaptation to long-term effects results in a reduction of SSR (9). However, studies assessing the results of Dutch Hunger Winter of 19441945 or of the Cuban economic crisis have not produced evidence to confirm this hypothesis $(37,38)$. James reported that normal values of gonadal hormones like testosterone and oestrogen reflect the health status of women and men, and are associated with an increase in SSR; in contrast, high levels of gonadotrophic hormones (FSH, $\mathrm{LH}$ ) reflect an unhealthy status and are associated with a decrease in the ratio in his research and reviews about sex ratios (39-41). Low SSR in people with dioxin, dibromochloropropane (DBCP) exposure, which have strong anti-oestrogenic and anti-androgenic effects on environmental pollution, are considered among the factors associated with endocrine disruptive chemicals, which support this view $(30,42)$. In industrialised North American and Northern European countries, increasing pollution leading to endocrinologic destruction has been suggested to be responsible for the decrease in SSR in recent decades (43).

Contrary to the hypothesis that secondary sex ratio variation reflects changes in the primary sex ratio, another hypothesis suggests that the secondary sex ratio decreases due to an increase in embryo/foetal loss after major disasters (44). In fact, we know that more male babies are lost in the early weeks of gestation. SSR in patients with miscarriage at 16-19 weeks of gestation, at 20 weeks of gestation, and delivery after 36 weeks of gestation were 248:100; 130:100; and 105:100, respectively (45). The answer of the question of whether the embryo loss rate increases after large earthquakes, however, is not yet clear. Catalano and Bruckner reported severe psychological stress after the 9/11 terrorist attacks, economic crises, and in collective dismissal issues, all of which reduce SSR (44, 46-48). In their study investigating the effects of stress after the 9/11 terrorist attack, they stated the reduction in SSR, not after 8, 9 and 10 months, but within the first 3 months, suggesting that this result is not related to fertilisation, but rather a greater increase in loss associated with male foetuses (46). According to this hypothesis, when the mother's health is in danger, weak male foetuses are sacrificed more by glucocorticoid levels compared with female foetuses. Hobel et al. have shown that after 20 weeks of gestation, after maturation of the foetal nervous system, foetuses are more susceptible to elevated maternal glucocorticoids, which was associated 
with preterm birth (49). However, pregnancy is a process where sensitivity to the effects of stress from the outside is decreased. For example, during pregnancy, compared with a non-pregnant period, more corticotrophin releasing hormone (CRH) is needed for adrenocorticotropin hormone (ACTH) response (50). Also, pregnancy is characterised by decreased vascular response to epinephrine and norepinephrine infusion, reduced heart rate and blood pressure response to physical stressors (51). This insensitivity gradually increases in the following weeks of gestation (52). After the Northridge earthquake in California, US, in 1994, the emotional effects of earthquakes were found to be higher during early pregnancy and stress encountered in early pregnancy is shown to shorten the duration of pregnancy (53).

Another point that has to be explained for the foetal loss hypothesis is whether all of the foetuses are affected by stressor factors. Catalano et al. have shown in their study that weak foetuses are lost due to stress, or if they survive are not damaged, and such cohorts of individuals born later in their lives are not associated with increased morbidity and mortality (culled cohort hypothesis) (54). However, a cohort of babies born from damaged foetuses are associated with an increased morbidity and mortality risk in the future (damaged cohort hypothesis) $(55,56)$. The knowledge that such infants born during periods of stress have an increased risk of metabolic, cardiac and psychiatric illness in their adulthood and a reduced life expectancy found a place in the literature $(14,57,58)$. As shown by Van den Berg et al., mortality rates are higher and the average life expectancy is 10 months shorter in patients > 35 years of age in times of economic recession compared with patients born in times of good economic status (14). Similarly, the study by Dama has shown an inverse proportion of SSR with the future mortality rate (58). If stress has occurred as a consequence of a disaster like an earthquake affecting the whole society, these diseases can become a public health problem 10 years later, so this may be an early marker of decreased SSR. Another creation of a community health plan might be required in cohorts with decreased secondary sex ratios after the earthquake.

In our study, we saw a significant decrease in secondary sex ratio about 8 months later when comparing the affected region with the unaffected area. This reduction was specific to only one month. First, Fukuda et al. (7) reported a significant decrease in the sex ratio 9 months after the Kobe earthquake. In the following years, Saadat et al. (11) stated that the psychological tension and stress as a consequence of the Ban earthquake was associated with a reduction in the sex ratio 6-12 months after and Tourikis at al. (13) found a significant decline in the sex ratio within a two month period starting from the 11th month after the Zakynthos earthquake. Torch et al. (12) stated in their study investigating the Tarapaca earthquake that the effects of the earthquake were significant on foetuses exposed during the 2nd or 3rd months of pregnancy, which resulted in a decrease in the sex ratio during birth. Our results support the studies indicating that the abortion rate of male foetuses exposed to the earthquake during the first trimester was higher than that of female embryos and indicates that the interaction was highest in the first month after the earthquake. A reduction in SSR after smoke pollution in London and the Brisbane flood occurred 320 days after the disaster; however, we did not determine such a long effect (8). Another factor with an impact on our results was an increase in preterm birth rates. If male babies are lost and female babies are born prematurely, then the reduction in SSR should be prior to 9 months of pregnancy. We have not had the chance to access hospital-based records, so we do not have data about an increasing preterm birth rate. After the earthquake in Golcuk, aftershocks continued for months and almost 3 months later a second major earthquake occurred; if we keep this in mind, it is difficult to explain why eight months after the earthquake the SSR was significantly decreased in just one month. The normalisation of the SSR after the acute loss of weak embryos as a response to stressful events can be one of the explanations. Further studies are needed to determine the adaptation rate to sudden stressful events during pregnancy. However, other studies have examined changes in the sex ratio at birth after earthquakes, and it should be kept in mind that the difference in SSR was significant only for a short period of time or a few months. Tan et al. (25) evaluated the effects of earthquakes in pregnancy after the Wenchuan Earthquake (2008, China) and did not detect a significant difference in SSR. However, the selective abortion of female infants in China is a common practice; as a result, it is not easy to determine changes in the SSR.

The effects of fire and related air and sea pollution in a large petrochemical refinery located very close to the city centre after 1999 Golcuk Earthquake can be discussed. Similarly, the smoke and air pollution following the Seveso accident, such as Minamata methylmercury pollution incidents, and the subsequent exposure of chemicals has been shown to lead to a decrease in SSR (8, 59-61). Moreover, if this argument is correct, the decrease in SSR can be used as an indicator of environmental pollution leading to a change in the nature of effects, and can be used for general health to take action on this issue. However, the most interesting thing is that the study by Yang et al. (62) of people living around the petrochemical refinery in Taiwan, and the study by Saadat et al. (63) about people living in areas of oil and natural gas have shown an increase in SSR as a contrast. It should be kept in mind that the Gulf of Izmit is located in the epicentre of the earthquake, and was in the region of the country's most intense air and marine pollution for 25 years before the earthquake. It is difficult to separately reflect the effects of the earthquake and environmental pollution on the statistics. In conclusion, our study indicated that, as a consequence of the probable abortion of male embryos after large earthquakes, a significant reduction in the secondary sex ratio has been detected for a short period of time. With these findings, events that cause sudden intense stress, such as earthquakes, can have effects on the sex ratio at birth.

Ethics Committee Approval: N/A

Informed Consent: $N / A$

Peer-review: Externally peer-reviewed.

Author contributions: Concept - E.D., E.Ç.; Data Collection\&/or Processing - E.D., H.U.Sु.; Analysis\&/or Interpretation - E.D., Y.Ç., 
E.C..; Literature Search - SS.Y.K., Y.C.; Writing - E.D., Y.Ç.; Critical Reviews - E.Ç..

\section{Conflict of Interest: No conflict of interest was declared by the} authors.

Financial Disclosure: No financial disclosure was declared by the authors..

\section{References}

1. Taylor KC, Jackson LW, Lynch CD, Kostyniak PJ, Buck Louis GM. Preconception maternal polychlorinated biphenyl concentrations and the secondary sex ratio. Environ Res 2007; 103: 99-105. [CrossRef]

2. Chahnazarian A. Determinants of the sex ratio at birth: review of recent literature. Soc Biol 1988; 35: 214-35.

3. Cheng H. On sex ratios at birth and in childhood. China Popul Today 1997; 14: 25 .

4. Helle S, Helama S, Lertola K. Evolutionary ecology of human birth sex ratio under the compound influence of climate change, famine, economic crises and wars. J Anim Ecol 2009; 78: 1226-33. [CrossRef]

5. Farhud DD, Kamali MS, Marzban M. Seasonality of birth and sex ratio in Tehran, Iran. Anthropol Anz 1986; 44: 61-6.

6. Chacon-Puignau GC, Jaffe K. Sex ratio at birth deviations in modern Venezuela: the Trivers-Willard effect. Soc Biol 1996; 43: 257-70.

7. Fukuda M, Fukuda K, Shimizu T, Møller H. Decline in sex ratio at birth after Kobe earthquake. Hum Reprod 1998; 13: 2321-2. [CrossRef]

8. Lyster WR. Altered sex ratio after the London smog of 1952 and the Brisbane flood of 1965. J Obstet Gynaecol Br Commonw 1974; 81: 626-31. [CrossRef]

9. Song S. Does famine influence sex ratio at birth? Evidence from the 1959-1961 Great Leap Forward Famine in China. Proc Biol Sci 2012; 279: 2883-90. [CrossRef]

10. Saadat M, Ansari-Lari M. Sex ratio of birth during wartime and psychological tensions. Hum Reprod 2004; 19: 465. [CrossRef]

11. Saadat M. Decline in sex ratio at birth after Bam (Kerman Province, Southern Iran) earthquake. J Biosoc Sci 2008; 40: 935-7. [CrossRef]

12. Torche F, Kleinhaus K. Prenatal stress, gestational age and secondary sex ratio: the sex-specific effects of exposure to a natural disaster in early pregnancy. Hum Reprod 2012; 27: 558-67. [CrossRef]

13. Tourikis JD, Beratis IN. Community psychological stressor-induced secondary sex ratio decline after a seismic sequence in the Greek island of Zakynthos. J Biosoc Sci 2013; 45: 231-8. [CrossRef]

14. Van den Berg GJ, Doblhammer G, Christensen K. Exogenous determinants of early-life conditions, and mortality later in life. Soc Sci Med 2009; 68: 1591-8. [CrossRef]

15. Alkan N, Elmas I, Karakus M, Akkay E. Problems encountered during natural disasters: a questionnaire study. Ulus Travma Derg 2001; 7: 195-9.

16. Boğaziçi University, Kandilli Observatory and Earthquake Research Enstitute, The Bulletin of National Earthquake Monitoring Center, 1999 http://www.koeri.boun.edu.tr/sismo/

17. Hansen D, Moller H, Olsen J. Severe periconceptional life events and the sex ratio in offspring: follow up study based on five national registers. BMJ 1999; 319: 548-9. [CrossRef]

18. Khashan AS, Mortensen PB, McNamee R, Baker PN, Abel KM. Sex ratio at birth following prenatal maternal exposure to severe life events: a population-based cohort study. Hum Reprod 2009; 24: 1754-7. [CrossRef]

19. Obel C, Henriksen TB, Secher NJ, Eskenazi B, Hedegaard M. Psychological distress during early gestation and offspring sex ratio. Hum Reprod 2007; 22: 3009-12. [CrossRef]
20. Subbaraman MS, Goldman-Mellor SJ, Anderson ES, Lewinn KZ, Saxton KB, Shumway M, et al. An exploration of secondary sex ratios among women diagnosed with anxiety disorders. Hum Reprod 2010; 25: 2084-91. [CrossRef]

21. Onder E, Tural U, Aker T, Kiliç C, Erdoğan S. Prevalence of psychiatric disorders three years after the 1999 earthquake in Turkey: Marmara Earthquake Survey (MES). Soc Psychiatry Psychiatr Epidemiol 2006; 41: 868-74. [CrossRef]

22. Chang HL, Chang TC, Lin TY, Kuo SS. Psychiatric morbidity and pregnancy outcome in a disaster area of Taiwan 921 earthquake. Psychiatry Clin Neurosci 2002; 56: 139-44. [CrossRef]

23. Torche $F$. The effect of maternal stress on birth outcomes: exploiting a natural experiment. Demography 2011; 48: 1473-91. [CrossRef]

24. Watson JB, Mednick SA, Huttunen M, Wang X. Prenatal teratogens and the development of adult mental illness. Dev Psychopathol 1999; 11: 457-66. [CrossRef]

25. Tan CE, Li HJ, Zhang XG, Zhang H, Han PY, An Q, et al. The impact of the Wenchuan earthquake on birth outcomes. PLoS One 2009; 4: e8200. [CrossRef]

26. Montenegro MA, Palomino $\mathrm{H}$, Palomino HM. The influence of earthquake-induced stress on human facial clefting and its simulation in mice. Arch Oral Biol 1995; 40: 33-7. [CrossRef]

27. Fukuda M, Fukuda K, Shimizu T, Yomura W, Shimizu S. Kobe earthquake and reduced sperm motility. Hum Reprod 1996; 11: 1244-6. [CrossRef]

28. Martin JF. Hormonal and behavioral determinants of the secondary sex ratio. Soc Biol 1995; 42: 226-38.

29. Brewis AA. Sex ratios at birth in a Micronesian Atoll population. Soc Biol 1993; 40: 207-14.

30. Jarrell J. Rationale for the study of the human sex ratio in population studies of polluted environments. Cad Saude Publica 2002; 18 : 429-34. [CrossRef]

31. Wilcox AJ, Weinberg CR, Baird DD. Timing of sexual intercourse in relation to ovulation. Effects on the probability of conception, survival of the pregnancy, and sex of the baby. N Engl J Med 1995; 333: 1517-21. [CrossRef]

32. Gray RH, Simpson JL, Bitto AC, Queenan JT, Li C, Kambic RT, et al. Sex ratio associated with timing of insemination and length of the follicular phase in planned and unplanned pregnancies during use of natural family planning. Hum Reprod 1998; 13: 1397-400. [CrossRef]

33. Trivers RL, Willard DE. Natural selection of parental ability to vary the sex ratio of offspring. Science 1973; 179: 90-2. [CrossRef]

34. Clutton-Brock TH, Iason GR. Sex ratio variation in mammals. Q Rev Biol 1986; 61: 339-74. [CrossRef]

35. Bulik CM, Holle AV, Gendall K, Lie KK, Hoffman E, Mo X, et al. Maternal eating disorders influence sex ratio at birth. Acta Obstet Gynecol Scand 2008; 87: 979-81. [CrossRef]

36. James WH. Sex ratio of offspring of diabetics. Lancet 1998; 351 : 1514. [CrossRef]

37. Stein AD, Zybert PA, Lumey LH. Acute undernutrition is not associated with excess of females at birth in humans: the Dutch hunger winter. Proc Biol Sci 2004; 271 Suppl 4: S138-41. [CrossRef]

38. Venero Fernández SJ, Medina RS, Britton J, Fogarty AW. The association between living through a prolonged economic depression and the male:female birth ratio--a longitudinal study from Cuba, 1960-2008. Am J Epidemiol 2011; 174: 1327-31. [CrossRef]

39. James WH. Hypotheses on mammalian sex ratio variation at birth. J Theor Biol 1998; 192: 113-6. [CrossRef]

40. James WH. Evidence that mammalian sex ratios at birth are partially controlled by parental hormone levels around the time of conception. J Endocrinol 2008; 198: 3-15. [CrossRef] 
41. James $\mathrm{WH}$. The categories of evidence relating to the hypothesis that mammalian sex ratios at birth are causally related to the hormone concentrations of both parents around the time of conception. J Biosoc Sci 2011; 43: 167-84. [CrossRef]

42. James WH. Offspring sex ratios at birth as markers of paternal endocrine disruption. Environ Res 2006; 100: 77-85. [CrossRef]

43. Grech V, Vassallo-Agius P, Savona-Ventura C. Secular trends in sex ratios at birth in North America and Europe over the second half of the 20th century. J Epidemiol Community Health 2003; 57: 612-5. [CrossRef]

44. Catalano R, Bruckner T, Marks AR, Eskenazi B. Exogenous shocks to the human sex ratio: the case of September 11, 2001 in New York City. Hum Reprod 2006; 21: 3127-31. [CrossRef]

45. Jongbloet PH. Fetal sex and very preterm birth. Am J Obstet Gynecol 2005; 193: 302. [CrossRef]

46. Bruckner TA, Catalano R, Ahern J. Male fetal loss in the U.S. following the terrorist attacks of September 11, 2001. BMC Public Health 2010; 10: 273-8. [CrossRef]

47. Catalano R, Bruckner T, Anderson E, Gould JB. Fetal death sex ratios: a test of the economic stress hypothesis. Int $\mathrm{J}$ Epidemiol 2005; 34: 944-8. [CrossRef]

48. Catalano R, Zilko CE, Saxton KB, Bruckner T. Selection in utero: a biological response to mass layoffs. Am J Hum Biol 2010; 22: 396-400. [CrossRef]

49. Hobel CJ, Dunkel-Schetter C, Roesch SC, Castro LC, Arora CP. Maternal plasma corticotropin-releasing hormone associated with stress at 20 weeks' gestation in pregnancies ending in preterm delivery. Am J Obstet Gynecol 1999; 180(1 Pt3): S257-63. [CrossRef]

50. Schulte HM, Weisner D, Allolio B. The corticotrophin releasing hormone test in late pregnancy: lack of adrenocorticotrophin and cortisol response. Clin Endocrinol (Oxf) 1990; 33: 99-106. [CrossRef]

51. Nisell H, Hjemdahl P, Linde B, Lunell NO. Sympatho-adrenal and cardiovascular reactivity in pregnancy-induced hypertension. I. Responses to isometric exercise and a cold pressor test. $\mathrm{Br} \mathrm{J}$ Obstet Gynaecol 1985; 92: 722-31. [CrossRef]

52. Glynn LM, Schetter CD, Wadhwa PD, Sandman CA. Pregnancy affects appraisal of negative life events. J Psychosom Res 2004; 56: 47-52. [CrossRef]
53. Glynn LM, Wadhwa PD, Dunkel-Schetter C, Chicz-Demet A, Sandman CA. When stres happens matters: effects of earthquake timing on stress responsivity in pregnancy. Am J Obstet Gynecol 2001; 184: 637-42. [CrossRef]

54. Catalano R, Bruckner T. Secondary sex ratios and male lifespan: damaged or culled cohorts. Proc Natl Acad Sci U S A 2006; 103: 1639-43. [CrossRef]

55. Catalano R, Bruckner T. Male lifespan and the secondary sex ratio. Am J Hum Biol 2006; 18: 783-90. [CrossRef]

56. Bruckner T, Catalano R. The sex ratio and age-specific male mortality: evidence for culling in utero. Am J Hum Biol 2007; 19: 763-73. [CrossRef]

57. Seckl JR, Holmes MC. Mechanisms of disease: glucocorticoids, their placental metabolism and fetal 'programming' of adult pathophysiology. Nat Clin Pract Endocrinol Metab 2007; 3: 479-88. [CrossRef]

58. Dama MS. Sex ratio at birth and mortality rates are negatively related in humans. PLoS One 2011; 6: e23792. [CrossRef]

59. Williams FL, Lawson AB, Lloyd OL. Low sex ratios of births in areas at risk from air pollution from incinerators, as shown by geographical analysis and 3-dimensional mapping. Int J Epidemiol 1992; 21: 311-9. [CrossRef]

60. Mocarelli P, Brambilla P, Gerthoux PM, Patterson DC, Needham LL. Change in sex ratio with exposure to dioxin. Lancet 1996; 348: 409. [CrossRef]

61. Sakamoto M, Nakano A, Akagi H. Declining Minamata male birth ratio associated with increased male fetal death due to heavy methylmercury pollution. Environ Res 2001; 87: 92-8. [CrossRef]

62. Yang CY, Tsai SS, Cheng BH, Hsu TY, Wu TN. Sex ratio at birth associated with petrochemical air pollution in Taiwan. Bull Environ Contam Toxicol 2000; 65: 126-31. [CrossRef]

63. Saadat M, Ansari-Lari M, Bahaoddini A. Sex ratio at birth in Masjid-iSulaiman (Khozestan province, Iran). Occup Environ Med 2002; 59: 853. [CrossRef] 